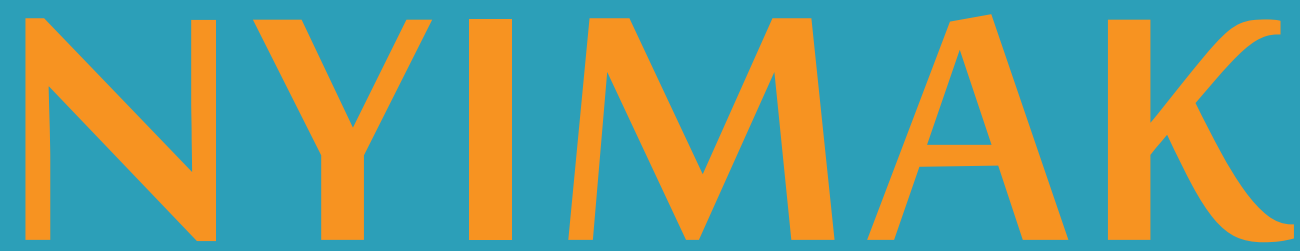

\title{
Journal of Communication
}

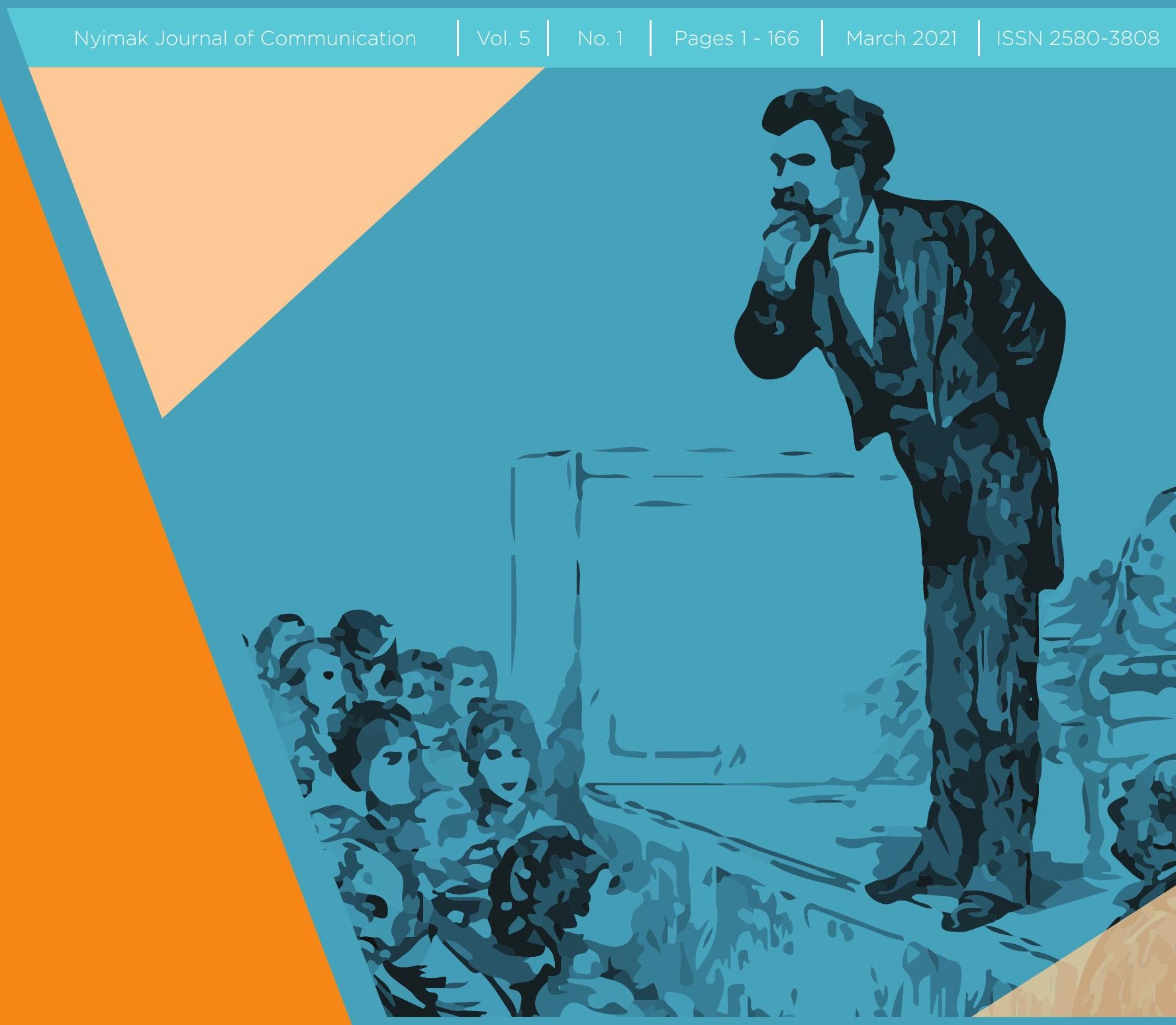

Department of Communication Science Faculty of Social and Political Science Universitas Muhammadiyah Tangerang 


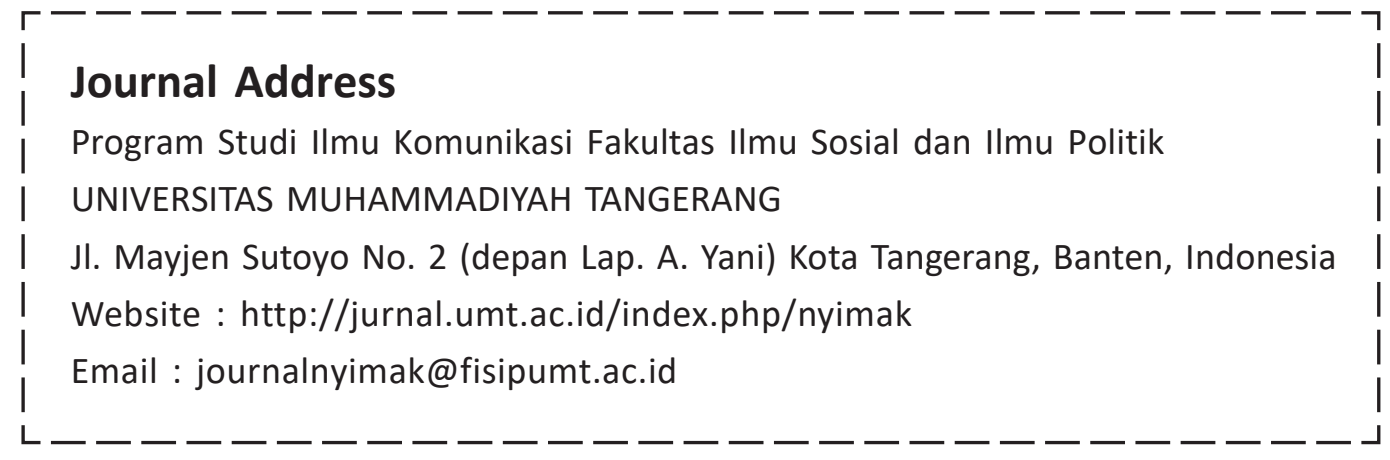




\section{NYIMAK Journal of Communication}

\section{DAFTAR ISI (TABLE OF CONTENT)}

Case Study in Covid-19 Infodemic in Indonesia

—Ferdinand Eskol Tiar Sirait, Rati Sanjaya-

Kredit Usaha Rakyat (KUR) Regulation and Communication Factors towards Farmer Independence

-Anna Gustina Zainal, Toni Wijaya, Selly Oktarina, Eko Wahyono, Pairulsyah-

Communicative Model of Presidential Chief of Staff in Decision

Making of Public Policy

-Henni Gusfa, Gun Gun Heryanto, Tuti Widiastuti, Rita Nurlitasetia, Yofrina Gultom-

Intercultural Communication in Manuscript Digitization

(Study in the Village of Legok Indramayu)

-Tantry Widiyanarti, Sarwititi Sarwoprasodjo, Ahmad Sihabudin, Rilus A. Kinseng-

Disaster Communication Representation on BNPB's Instagram

as COVID-19 Response Acceleration Task Force

- Lestari Nurhajati, Amanda Pramarta Putri, Xenia Angelica

Wijayanto-

Social Media, Digital Activism, and Online Gender-Based Violence in Indonesia

—Eny Ratnasari, Suwandi Sumartias, Rosnandar Romli-

Mapping of Research Publications Concerning Disabilities and 
The 2019 Indonesian Presidential Election: Propaganda in Post-Truth $135-150$ -Akhirul Aminulloh, Myrtati Dyah Artaria, Yuyun Wahyu Izzati Surya, Kamil Zajaczkowski-

Performance of Indonesian Ministry of Health in Overcoming Hoax $151-166$ About Vaccination Amid the COVID-19 Pandemic on Social Media - Daniel Susilo, Teguh Dwi Putranto, Charles Julian Santos Navarro- 


\title{
Performance of Indonesian Ministry of Health in Overcoming Hoax About Vaccination Amid the COVID-19 Pandemic on Social Media
}

\author{
Daniel Susilo ${ }^{1}$, Teguh Dwi Putranto ${ }^{2}$, Charles Julian Santos Navarro ${ }^{3}$ \\ ${ }^{1}$ Universitas Multimedia Nusantara \\ JI. Scientia Boulevard, Gading, Tangerang 15227 \\ ${ }^{2}$ Universitas Airlangga \\ Jl. Airlangga No. 4-6, Surabaya \\ 3 University of Buenos Aires \\ Viamonte 430, C1053 CABA, Argentina \\ Email: daniel.susilo@umn.ac.id ${ }^{1}$, teguhdp@gmail.com², charles.santos.navarro@gmail.com³
}

\begin{abstract}
The coronavirus disease (COVID-19) pandemic in early 2021 is still a "big disaster" for Indonesia. The public is increasingly confused about the Government's Vaccination program in reducing the number of COVID-19 cases in Indonesia. The development of Vaccine-related hoaxes such as safe or not, halal or not, has also become a new job faced by the Government, especially the Ministry of Health. This study aims to determine the Indonesian Ministry of Health's performance in overcoming hoaxes against Vaccinations during the Covid-19 pandemic. The method used in this research is Krippendorff content analysis on Instagram posts of the Ministry of Health @kemenkes_ri during the period 1 January 2021 to 29 January 2021. The conclusion obtained in this study is that the Ministry of Health's efforts in dealing with hoaxes circulating in the community regarding the Covid-19 Vaccination are by presenting health experts in providing information related to the Covid-19 Vaccine. The information conveyed is related to the quality and safety of Vaccines, to the Vaccine development process.
\end{abstract}

Keywords: Performance, social media, hoax, vaccination, COVID-19

\section{ABSTRAK}

Pandemi penyakit coronavirus (COVID-19) di awal tahun 2021 masih menjadi "bencana besar" bagi Indonesia. Masyarakat semakin bingung dengan program vaksinasi yang dilakukan Pemerintah dalam menekan angka kasus COVID-19 di Indonesia. Berkembangnya hoaks terkait vaksin seperti aman atau tidak, halal atau tidak, juga menjadi pekerjaan baru yang dihadapi Pemerintah, khususnya Kementerian Kesehatan. Penelitian ini bertujuan untuk mengetahui kinerja Kementerian Kesehatan RI dalam mengatasi hoaks terhadap vaksinasi selama pandemi Covid-19. Metode yang digunakan dalam penelitian ini adalah analisis konten Krippendorff pada postingan Instagram Kementerian Kesehatan @kemenkes_ri selama periode 1 Januari 2021 hingga 29 Januari 2021. Kesimpulan yang diperoleh dalam penelitian ini adalah bahwa upaya yang dilakukan oleh Kementerian Kesehatan dalam menghadapi hoaks yang beredar di masyarakat terkait vaksinasi Covid-19 adalah dengan menghadirkan pakar kesehatan dalam memberikan informasi terkait vaksin Covid-19. Informasi yang disampaikan terkait dengan kualitas dan keamanan vaksin, hingga proses pengembangan vaksin.

Kata Kunci: Kinerja, media sosial, hoaks, vaksinasi, COVID-19

Citation : Susilo, Daniel, Teguh Dwi Putranto \& Charles J. Santos Navarro. (2021). "Performance of Indonesian Ministry of Health in Overcoming Hoax About Vaccination Amid the COVID-19 Pandemic on Social Media". Nyimak Journal of Communication, 5(1): 151-166. 


\section{INTRODUCTION}

Coronavirus Disease (COVID-19) is a newly discovered coronavirus disease (Rothan \& Byrareddy, 2020);(Sun et al., 2020). COVID-19 is the most recently discovered infectious coronavirus disease. Before the discovery and outbreak of the pandemic in Wuhan, China, in December 2019, this virus and disease had been unknown (World Health Organization, 2020). Coronavirus is non-mosaic, consisting of almost half of the genome of various beta coronavirus lines. The genomic characteristics of Coronavirus and the probable human link to viral characteristics and virulence need further study (Paraskevis et al., 2020). Many people worldwide are infected with the COVID-19 virus, which generally attacks the respiratory tract, can be mild, moderate, and can recover without special treatment (Zheng et al., 2020).

Indonesia is one of the countries that is affected by COVID-19. Indonesia recorded its first coronavirus case on 2 March 2020 (Nugroho, 2020). Positive cases of COVID-19 reached $1,012,350$ persons on Tuesday (26/1). Collaboration and synergy between sectors and programs, as well as community contributions, are expected to overcome the COVID-19 pandemic in Indonesia as soon as possible (Kemkes.go.id, 2021). The COVID-19 pandemic has contributed to a series of short-term policies for its people. One of them is policy in the field of education, namely the learning process at home online (Haryono et al., 2020). To combat this condition, one of the efforts taken by the Government is to Vaccinate the public.

Vaccines are the most efficient and cost-effective way to prevent infectious diseases (Makmun \& Hazhiyah, 2020). Indonesia still needs to take another 100 million doses before it is ready to start mass immunization with COVID-19 (Dwipayana, 2020). The Minister of Health, Budi Gunadi Sadikin, has identified seven types of Covid-19 Vaccines to be used for Vaccination in Indonesia. The types of Covid-19 Vaccines that can be used in Indonesia are those produced by PT Bio Farma, AstraZeneca, Sinopharm, Moderna, Novavax Inc, Pfizer Inc and BioNTech, and Sinovac (Kompas.com, 2021a). Each type of Vaccine certainly has advantages and disadvantages of each.

First, PT Bio Farma become one of the Vaccines for Corona virus to be used in Indonesia. It was during its development, PT. Bio Farma has received a certificate stating that its production facilities are suitable to produce the Vaccine COVID-19. In addition to production, Bio Farma has also developed a digital integrated distribution system to ensure the quality assurance of Vaccines that will be given to the people of Indonesia. Second, AstraZeneca is a recombinant adenoviral vector Vaccine. Quoted from Very Well Health, recombinant Vaccines use a small portion of genetic material from pathogens, such as SARS-CoV-2, to trigger an immune response. Certain parts of the virus can be targeted, and this Vaccine is 
generally safe to use in large populations of people even those with chronic health problems or people with immune disorders. One drawback of recombinant adenoviral vector Vaccines is that booster injections may be required over time (Nabila, 2021).

Third, Sinopharm works by teaching the immune system to make SARS-CoV-2 coronavirus antibodies. Antibodies attach to viral proteins, such as the so-called protein spikes attached to their surface. After being Vaccinated with Sinopharm's COVID-19 Vaccine, the immune system may respond to live Corona virus infection. One type of immune cell, namely B cells, produces antibodies attached to the invader. Antibodies targeting protein spikes may prevent the virus from entering the cells. Fourth, Moderna use the RNA Messenger (mRNA). The Corona virus has a spike-like structure called the S protein on its surface. The COVID-19 mRNA Vaccine provides cell instructions on how to make an inoffensive portion of the $S$ protein. After Vaccination, the cells begin to make protein chunks and display them on the surface of the cells. The immune system will recognize that protein is not included and will begin to build up an immune response and develop antibodies (Nabila, 2021).

Fifth, Novavax Inc uses a specially made protein spike that mimics the natural spike protein of Coronavirus. This Vaccine works by inserting a protein that triggers an antibody response that blocks the ability of the future Coronavirus to bind to cells and prevent infection. This protein is combined with the Novavavax adjuvant Matrix-M, which is important for enhancing the immune response of the protein antigen. Sixth, Pfizer Inc and BioNTech use synthetic genes that are easier to create, so that they can be produced faster than conventional technology. This dormant virus does not cause disease but teaches the immune system to respond to resistance. With mRNA, the body is not injected with a dead or attenuated virus but is injected with the genetic code of the virus. As a result, the body will make proteins that stimulate the immune response. Seventh, Sinovac works to strengthen the immune system so that antibodies can fight against the Corona virus. This Vaccine is made using an inactivated virus platform or method. In this way, the body can learn to recognize the virus that causes COVID-19, SARS-COV-2, without facing the risk of serious infection. The Vaccine is given in two doses or requires two injections (Nabila, 2021). These different variants of the Vaccine do not mean that the community can choose it themselves, because Vaccination is also carried out with several considerations.

Acceptance of the COVID-19 Vaccine was strongly influenced by the baseline efficacy of the Vaccine. Preparing the general population to accept a Vaccine with relatively low efficacy may be difficult (Harapan et al., 2020). Indonesia has conducted a free COVID-19 Vaccination program since January 13, 2021. Where President Joko Widodo (Jokowi) received the first 
injection of the COVID-19 Vaccine developed by Sinovac (Anwar, 2021). Vaccinations will be carried out for $70 \%$ of the population of Indonesia. This means that there are 181.5 million people who will be given the Vaccine. The government has criteria and priorities for recipients of Vaccines. In addition, priority areas for recipients of Vaccines exist. The priority circles for Vaccine administration are as follows frontlines, military, lecturers, and politicians.

A recent survey conducted by a non-profit organization, the Kaiser Family Foundation, which deals with various national health issues in the United States, shows that some 27 per cent refuse to undergo COVID-19 Vaccination even though it is free and considered safe. The majority cited the potential side effects of the Vaccine as a major concern, as well as a lack of confidence in the government regarding its safety and efficacy. Given that this Vaccine is still relatively new and public doubts about the politicization that has arisen during the manufacturing process of this Vaccine are also raised. Many myths and hoaxes have circulated in the community about the COVID-19 Vaccine which has also become a factor that raises public doubts about undergoing Vaccination, such as why the Vaccine from China? Safe or not? arrived at the fear of Vaccines not Halal (Iman, 2020). Sentiment analysis on Twitter regarding opinions or opinions on the corona Vaccine was found to be $48 \%$ positive, $29 \%$ neutral, and $23 \%$ negative (Rakhmawati et al., 2020). So that there are still many people who feel afraid to Vaccinate because of the circulation of hoaxes in the community. This fear is increasingly spread to the effects felt after Vaccination. In fact, the effects that arise after Vaccination should not be a cause for concern. To be more precise, Imhoff and Lambertys (2020) examined whether belief in conspiracy theories that say the pandemic is a hoax was connected to less support for containment-related activity compared to believing the pandemic is caused by humans. This could mean more support for selfcentered prepping behavior. Speculations alleging that the coronavirus pandemic is a hoax with regards to refusals, hoaxes are anticipated to be associated with participate in containment-related events (e.g., hygiene, physical distancing). Also related about vaccines, rumors spread among social media about vaccines related with conspiracy.

Myth and storytelling being powerful communication tool to persuade people and encourage people (Eko \& Putranto, 2019; Murtiningsih, 2016). This lack of maturity will inevitably cause an intercultural contact dispute, which is very complex by nature due to interrelated cultural influences such as, but not limited to, the system of attitudes, traditions, modes of thought, patterns of communication, and the manner in which each community perceives and deals with conflict (Murtiningsih, 2016). 
The reaction from the Covid-19 Vaccination is almost the same as the reaction that occurs in the Vaccination process in general. Some of these reactions include local reactions (eg, pain, redness, swelling at the injection site. Other severe local reactions, eg cellulitis). Systemic reactions (such as fever, muscle pain throughout the body (myalgia), joint pain (atralgia), weakness, headaches). Other reactions (such as allergic reactions, such as urticaria, edema, anaphylactic reactions, Syncope (fainting) (Kompas.com, 2021b). The lack of public understanding of Vaccination is one of the problems that must be addressed by the Indonesian Ministry of Health as the Ministry responsible for health issues. So this research aims to see the performance of the Ministry of Health in overcoming hoaxes about Vaccinations during the Covid-19 pandemic.

\section{METHOD}

The method used in this research is the content analysis chosen to describe the aspects and characteristics of the post content. Content analysis is a systematic method for evaluating the content of messages and the transmission of messages or an analytical tool for monitoring and analyzing the communication activities of selected communicators (Krippendorff, 2018).

Researchers used two coders to ensure objectivity in coding and data collection. The reliability test was used to check the validity of the data collected and to determine the accuracy of the data, and two encoders were used.

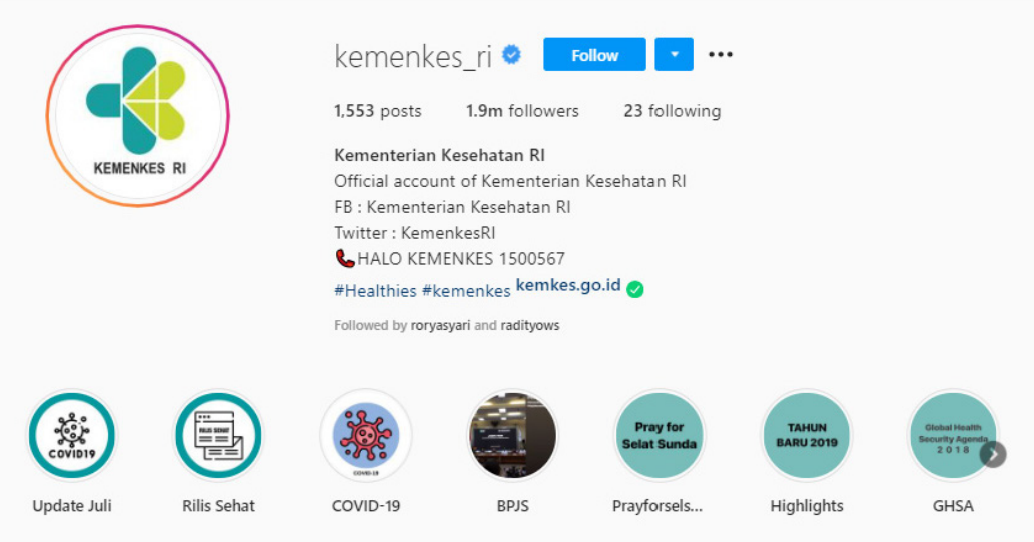

Figure 1. Ministry of Health Instagram Profile

Source: (Kemenkes_RI, 2021f) 
In addition, researchers also used an analysis of the content of Krippendorff to analyze Instagram posts. Researchers used content analysis to see Indonesian Ministry of Health performance at the beginning of 2021 via Instagram @kemenkes_ri during the period 1 January 2021 to 29 January 2021, as many as 27 posts were studied.

This study uses the Holsti formula to calculate data from the two coders (Holsti, 1969; Parker \& Holsti, 2006; Samiei \& Mehrabi, 2019). The content analysis method was chosen because the researchers tried quantitatively to see the content of Instagram posts, then the researchers tried to interpret post content, read symbols, and interpret the symbolic interaction content of Instagram posts @kemenkes_ri.

The steps taken by the researcher in this content analysis method are as follows: first, the researcher saw @kemenkes_ri Instagram posts during the period 1 January 2021 to 29 January 2021. Second, the researcher chose Instagram @kemenkes_ri to see posts that highlight the performance of Indonesian Ministry of Health. Third, after the posts are collected, the encoder will sort the posts. Fourth, the data collected is then processed and analyzed.

$$
\mathrm{PAo}=2 \mathrm{~A} /(\mathrm{N} 1+\mathrm{N} 2)
$$

Where PAo is the percentage of agreement between the two coders, $A$ is the number of decisions taken by the two coders, N1 and N2 are the number of decisions taken by the coder.

There are several indicators for measuring performance. The United Nations has formulated "good governance" indicators to include the following: (1) Capacity, that is, sufficient capacity to implement policies; government functions, including an efficient and responsive public administration system; (2) accountability of government activities and transparency in decision making; (3) participation in the democratic process through the use of public and private sources of information; (4) attention to equity and poverty; and (5) commitment to sound economic policies (Edralin, 1997). Out of the five indicators, the researcher chose to use three indicators, namely capacity, accountability, and participation. These three indicators were chosen because it is assumed that they represent several indicators that are widely used to assess the performance of public organizations within and outside the organization. 


\section{RESULTS AND DISCUSSION}

Researchers collected 27 posts from Instagram of Indonesian Ministry of Health @kemenkes_ri and used the Holsti formula to check data reliability. The performance indicators used are capacity, accountability, and participation.

Table 1. Post Analysis by Two Coders during 1 January 2021 to 29 January 2021

\begin{tabular}{|c|c|c|c|c|c|c|}
\hline \multirow[t]{2}{*}{ Date } & \multicolumn{3}{|c|}{ Coder 1} & \multicolumn{3}{|c|}{ Coder 2} \\
\hline & C & A & $\mathbf{P}$ & $\mathrm{C}$ & $A$ & $\mathbf{P}$ \\
\hline 1 & - & - & 2 & - & 1 & 1 \\
\hline 2 & - & - & - & - & - & - \\
\hline 3 & - & 1 & - & - & 1 & - \\
\hline 4 & - & - & - & - & - & - \\
\hline 5 & - & - & 1 & 1 & - & - \\
\hline 6 & - & - & - & - & - & - \\
\hline 7 & - & 1 & - & - & 1 & - \\
\hline 8 & - & - & - & - & - & - \\
\hline 9 & - & 1 & 2 & - & 2 & 1 \\
\hline 10 & - & - & 4 & - & - & 4 \\
\hline 11 & - & 1 & - & - & 1 & - \\
\hline 12 & 2 & 1 & - & 1 & 2 & - \\
\hline 13 & - & - & 2 & - & - & 2 \\
\hline 14 & - & - & - & - & - & - \\
\hline 15 & - & 1 & 1 & - & 1 & 1 \\
\hline 16 & - & - & 2 & - & - & 2 \\
\hline 17 & - & - & - & - & - & - \\
\hline 18 & - & 1 & - & - & 1 & - \\
\hline 19 & - & - & - & - & - & - \\
\hline 20 & - & - & - & - & - & - \\
\hline 21 & - & - & - & - & - & - \\
\hline 22 & - & - & - & - & - & - \\
\hline 23 & - & - & - & - & - & - \\
\hline 24 & - & - & 1 & - & - & 1 \\
\hline 25 & 1 & - & - & - & - & 1 \\
\hline 26 & - & - & 1 & - & - & 1 \\
\hline 27 & - & 1 & - & - & 1 & - \\
\hline Total & 3 & 8 & 16 & 2 & 11 & 14 \\
\hline
\end{tabular}

Source: (Researcher processed data, 2021) 
Table 1 shows the results of the coding process carried out by coder 1 and coder 2 on 27 posts that have been separated by date and their respective indicators. In addition, an overview of these indicators is described in Table 2.

Table 2. Coder Output

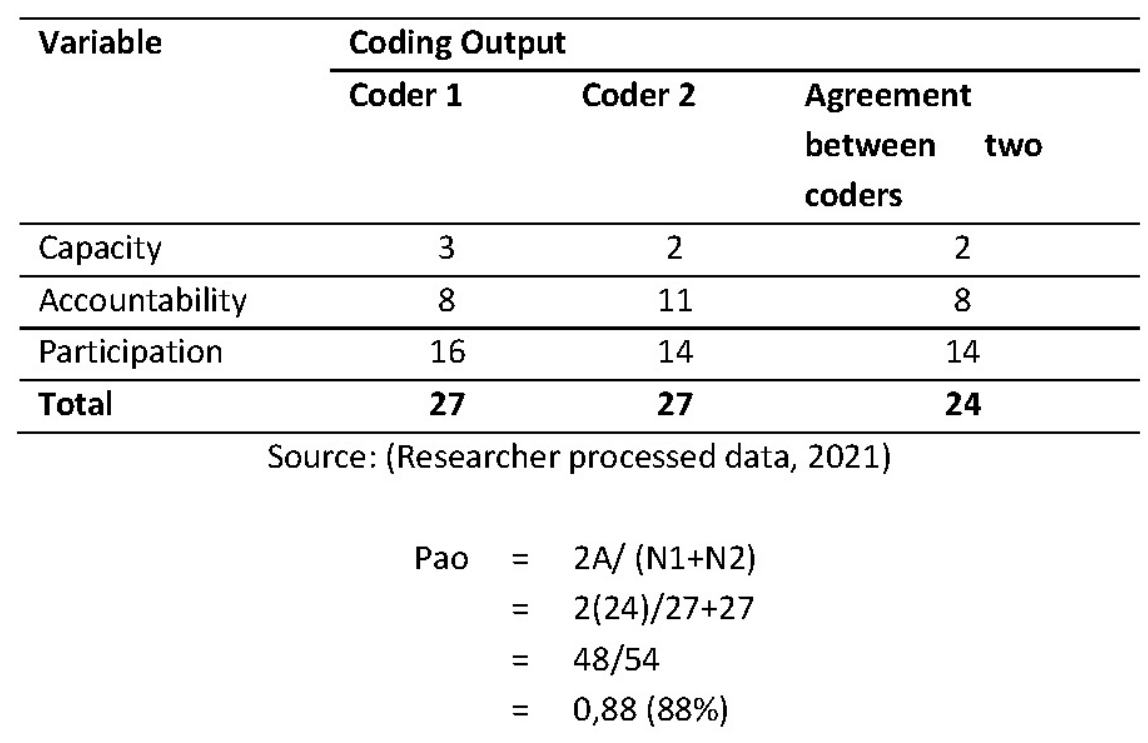

The data is said to be reliable if it can have a tolerance value of at least $70 \%$ or more than $0.7 \%$ (Holsti, 1969). The reliability element is 0.88 or $88 \%$ based on the results of the data calculations obtained using the Coder Holsti reliability formula. The data obtained is therefore declared to be reliable because it exceeds the minimum limit.

The results of coding that have been carried out on three indicators include capacity, accountability, and participation, participation indicators dominate the Instagram posts @kemenkes_ri. Posts related to participation during the period 1 January 2021 to 29 January 2021, appeared the most on 10 January 2021.

\section{Health Experts Talk about Vaccinations}

Through his Instagram account @kemenkes_ri during the period January 1, 2021 to January 29, 2021, the Indonesian Ministry of Health presented several health experts including Harif Fadhillah, SKp. SH (Chairman of the Indonesian National Nurses Association), Prof. Dr. Sri Rezeki Hadinegoro, dr., Sp.A(K) (Chairman of the Indonesian Technical Advisory Group on Immunization), and Prof. Dr. Kusnandi Rusmil, dr., Sp.A(K), M.M (Chairman of the COVID-19 Vaccine Clinical Trial Research Team) 


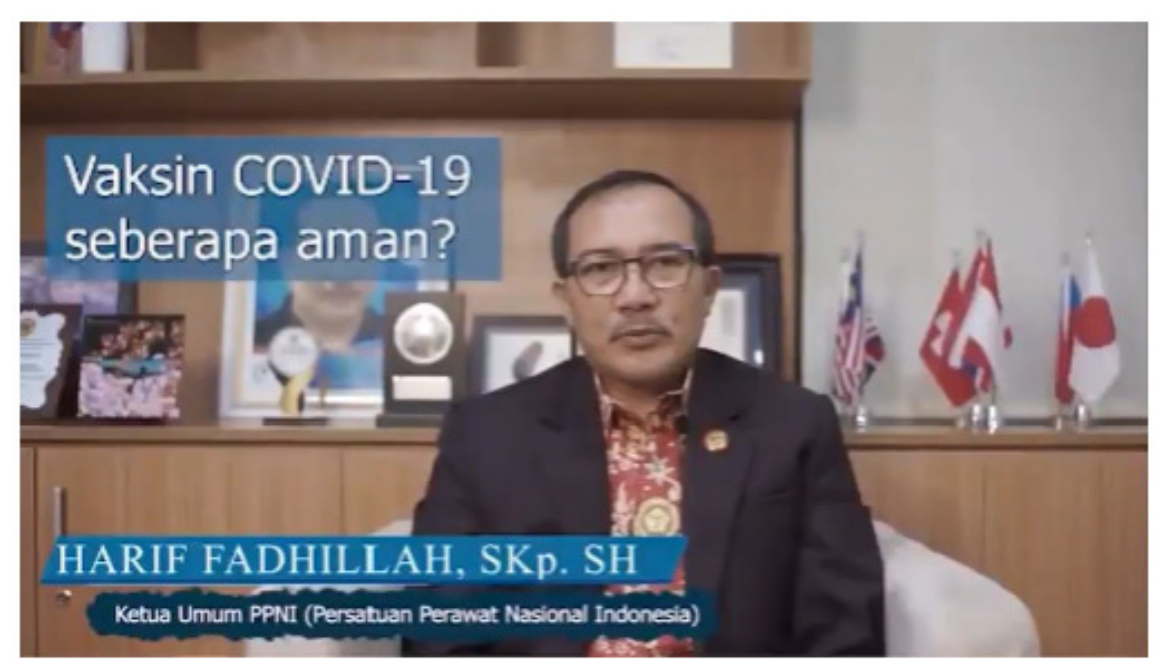

Figure 2. Chairman of the PPNI (Indonesian National Nurses Association) Source: (Kemenkes_RI, 2021c)

Based on the Instagram post (Figure 2), Harif Fadhillah, SKp. SH as Chairman of the PPNI (Indonesian National Nurses Association) advised health workers who were Vaccinated to be the priority group who received the Vaccine. Hanif also advised health workers not to hesitate to participate in the COVID-19 Vaccination because Vaccination can protect themselves and protect the country.

Small talk and whispers spread throughout the social domain of social contact and communications. Gossip and rumors can often be viewed as "information epidemiology," which spreads contiguously from person to person and place to place over time(Situngkir, 2004). Compare with previous epidemic (Avian Influenza), Indonesian Government responsive handling the issue and spiral of silence on the media (Abeysinghe \& White, 2011; Aditama et al., 2012). Meanwhile, disruption information among social media (Hearn \& Schoenhoff, 2016; Prasetiawan \& Maulina Ulfa, 2017; Sommerfeldt et al., 2019; D. Susilo et al., 2019) changes who's the trustee person to spreading the "True Information". Indonesian Ministry of Health trying to use the "Medical Person" instead of Social Media Influencer. 


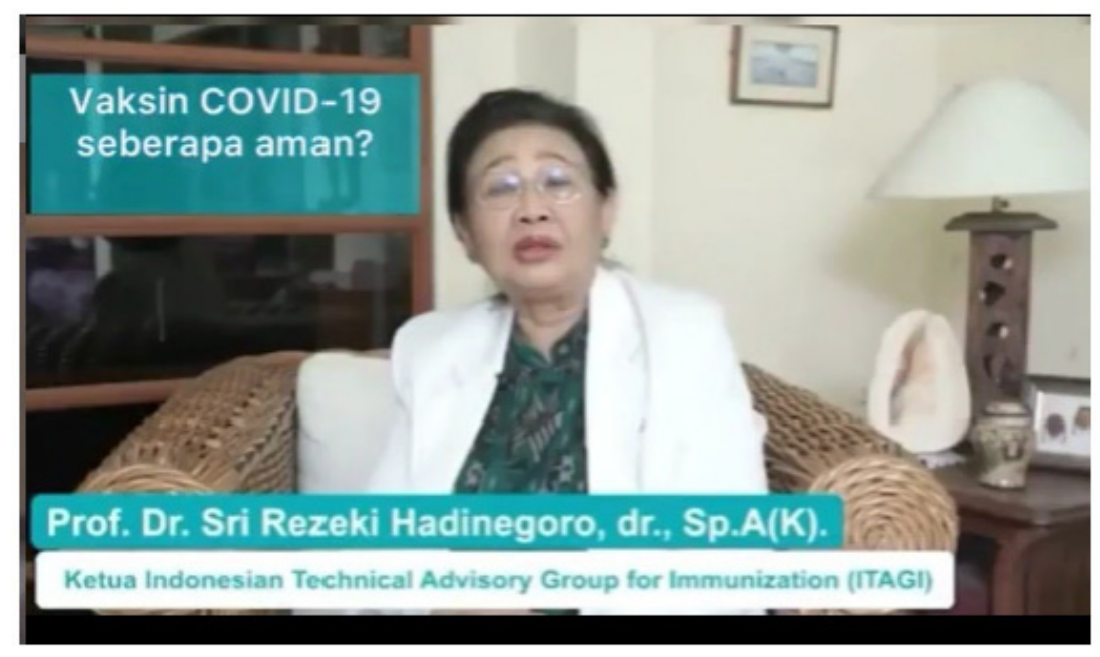

Figure 3. Chairman of the ITAGI (Indonesian Technical Advisory Group on Immunization) Source: (Kemenkes_RI, 2021b)

Based on the Instagram post (Figure 3), Prof. Dr. Sri Rezeki Hadinegoro, dr., Sp.A (K) as Chairman of the ITAGI (Indonesian Technical Advisory Group on Immunization) explained the quality and safety of the COVID-19 Vaccine.

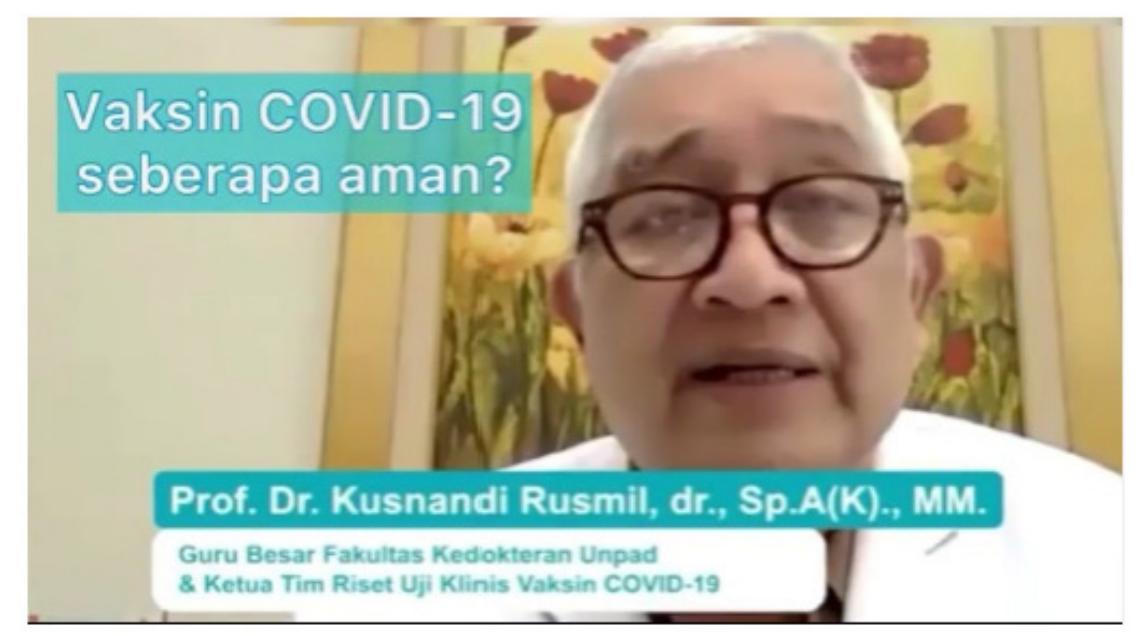

Figure 4. Chairman of the COVID-19 Vaccine Clinical Trial Research Team Source: (Kemenkes_RI, 2021a) 
Based on the Instagram post (Figure 4), Prof. Dr. Kusnandi Rusmil, dr., Sp.A(K), M.M as Chairman of the COVID-19 Vaccine Clinical Trial Research Team explained the the process of developing the COVID-19 Vaccine in Indonesia.

Compare with what really do in Japan and Singapore, the social media influencer giving more trust compare than expert to influence the level of trust on peoples (Enke \& Borchers, 2019; Ong \& Ito, 2019; Pang et al., 2016). The Ministry of Health absence to elaborate the level of people engagement of trust. The conservative method of facing the hoax and rumors only hit the baby boomers and non-digital native (Kosterlitz \& Lewis, 2017; Krishen et al., 2016; Leung, 2013). Compare with data by Susilo and Putranto (2018) most of the actively social media user are millenials and digital native.

\section{Giving public trust through appropriate information}

The Indonesian Ministry of Health provided the appropriate knowledge to the public through Instagram @kemenkes_ri related to the quality and safety of Vaccines, as well as the halalness of the Covid-19 Vaccine.

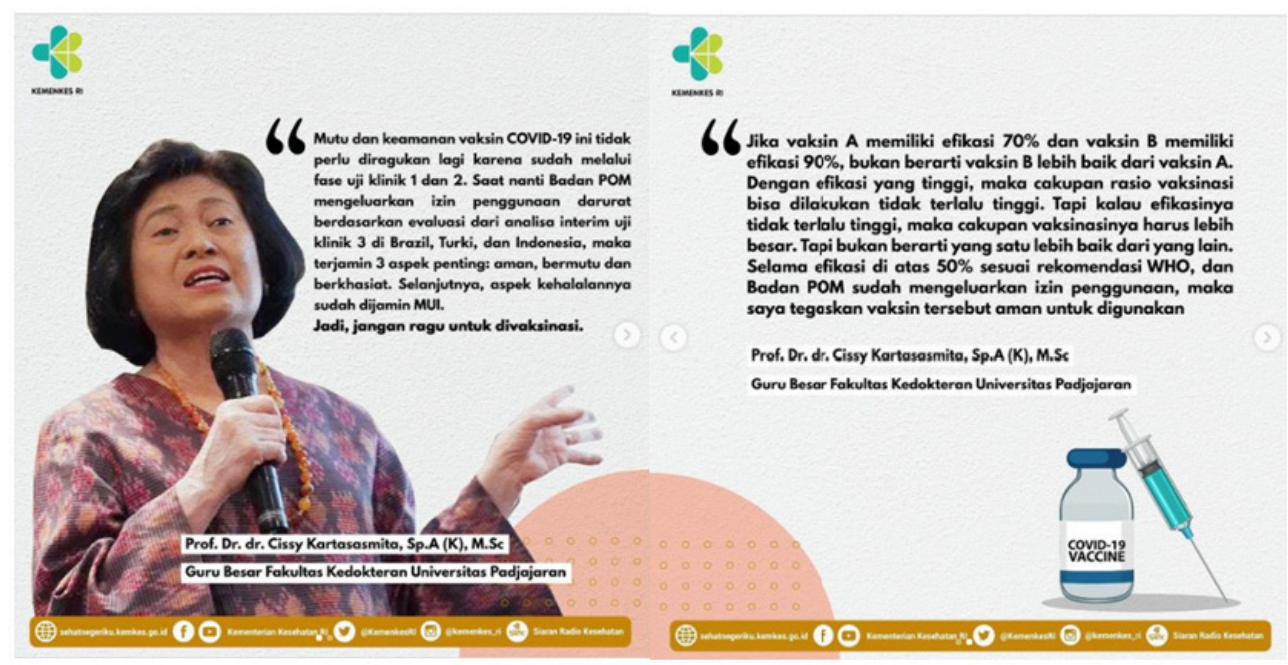

Figure 5. Instagram Posts Related to Vaccine Quality and Safety

Source: (Kemenkes_RI, 2021e)

Based on the Instagram post, people do not need to hesitate to be Vaccinated. Because the COVID-19 Vaccine has undergone a series of rigorous tests in a number of countries, including Indonesia. In addition to the halal aspects of the MUI, aspects of efficacy, quality 
and safety are the main issues. The World Health Organization (WHO) also states that Vaccines with efficacy in excess of $50 \%$ may be used by the wider community. Based on the results of the clinical trials, the side effects of the COVID-19 Vaccine are very mild and easy to overcome. It usually goes away within a day or two of Vaccination. People do not need to worry about and even fear Vaccinations, therefore. With Vaccination, not only do we protect ourselves, but we also protect our families and neighbors. Vaccination must not, however, lead to neglect and still discipline the application of the Health Protocol, namely wearing masks, keeping distances and washing hands with soap.

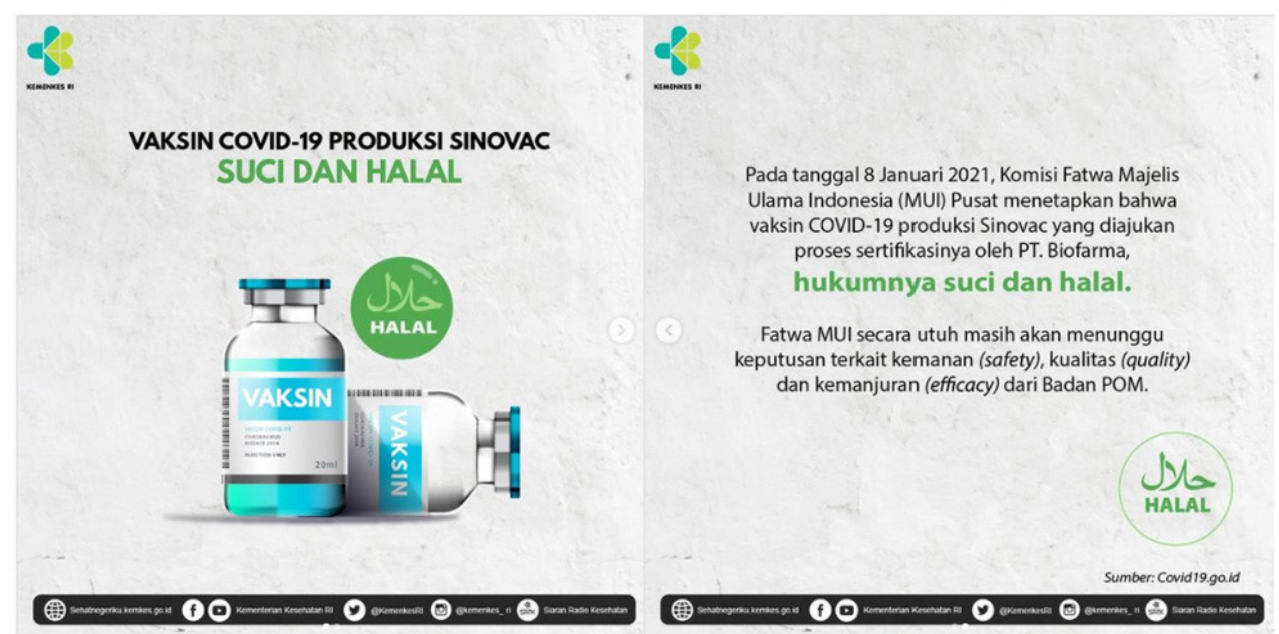

Figure 6. Instagram Posts Related to Holy and Halal Source: (Kemenkes_RI, 2021d)

Based on the Instagram post, application for halal certification from PT. Biofarma against the Sinovac Vaccine has undergone an audit process and was declared by Indonesian Ulema Council (MUI) through the MUI Fatwa No.2 of 2021 concerning the COVID-19 Vaccine Product from Sinovac Life Science.Co. Ltd and PT Biofarma, the law is holy and halal.

\section{CONCLUSION}

Based on data that has been collected through Instagram @kemenkes_ri and coded by the two coders, content containing Indonesian Ministry of Health participation indicators dominates posts on Instagram compared to posts related to capacity and accountability indicators during the period 1 January 2021 to 29 January 2021. Indonesian Ministry of Health 'performance in the @kemenkes_ri Instagram post is more towards The Indonesian Ministry 
of Health's participation in overcoming hoaxes is by presenting health experts to provide information related to the Covid-19 Vaccine. The information conveyed is related to the quality and safety of Vaccines, to the Vaccine development process. So that Vaccination can protect yourself, and also protect the country.

Focusing on medical experts rather than social media influencers, the Ministry of Health seems to have omitted details about people's involvement in trusting relationships. A conservative approach for dealing with hoaxes and rumors only impacted baby boomers and non-digital natives, but most of the people who are constantly on social media are millennials and digital natives.

\section{ACKNOWLEDGEMENT}

Susilo would express the gratitude to the Rector Universitas Multimedia Nusantara. Putranto would express the gratitude to the Dean of Faculty of Social and Political Sciences, Airlangga University, Prof. Bagong Suyanto. Navarro express thank for colleagues from University of Buenos Aires who provided insight and expertise that greatly assisted the research.

\section{REFERENCES}

Abeysinghe, S., \& White, K. (2011). The avian influenza pandemic: Discourses of risk, contagion and preparation in Australia. Health, Risk \& Society, 13(4), 311-326.

Aditama, T. Y., Samaan, G., Kusriastuti, R., Sampurno, O. D., Purba, W., Santoso, H., Bratasena, A., Maruf, A., Sariwati, E., \& Setiawaty, V. (2012). Avian influenza H5N1 transmission in households, Indonesia. PloS One, 7(1), e29971.

Anwar, F. (2021). Update 5 Jenis Vaksin COVID-19 dan Harganya di Indonesia.

Dwipayana, I. (2020). Efforts in Securing Vaccine for Covid-19 Outbreak in Indonesia. Health Notions, 4(10). https://doi.org/10.33846/hn41003

Edralin, J. (1997). The new local governance and capacity building: A strategic approach. Regional Development Studies, 3, 148-150.

Eko, B. S., \& Putranto, H. (2019). The Role of Intercultural Competence and Local Wisdom in Building Intercultural and Inter-religious Tolerance. Journal of Intercultural Communication Research. https://doi.org/10.1080/17475759.2019.1639535

Enke, N., \& Borchers, N. S. (2019). Social media influencers in strategic communication: A conceptual framework for strategic social media influencer communication. International Journal of Strategic Communication, 13(4), 261-277. 
Harapan, H., Wagner, A., Yufika, A., Winardi, W., Anwar, S., Gan, A., Setiawan, A., Rajamoorthy, Y., Sofyan, H., \& Mudatsir, M. (2020). Acceptance of a COVID-19 Vaccine in Southeast Asia: A Cross-Sectional Study in Indonesia. Frontiers in Public Health, 8. https://doi.org/ 10.3389/fpubh.2020.00381

Haryono, C., Marta, R., \& Chinmi, M. (2020). Discursive Intertextualities of RuangGuru due COVID-19 by the Governor of Central Java. Nyimak: Journal of Communication, 4(2), 233-247. https://doi.org/10.31000/nyimak.v4i2.2711

Hearn, A., \& Schoenhoff, S. (2016). From celebrity to influencer. In A Companion to Celebrity (pp. 194-210).

Holsti, O. R. (1969). Content analysis for the social sciences and humanities. Reading. MA: Addison-Wesley (Content Analysis).

Iman, D. (2020). Lawan Hoaks Vaksin COVID-19, Pakar Kesehatan: Masyarakat "Enggak Usah Takut."

Imhoff, R., \& Lamberty, P. (2020). A Bioweapon or a Hoax? The Link Between Distinct Conspiracy Beliefs About the Coronavirus Disease (COVID-19) Outbreak and Pandemic Behavior. Social Psychological and Personality Science, 11(8), 1110-1118. https://doi.org/ 10.1177/1948550620934692

Kemenkes_RI. (2021a). Chairman of the COVID-19 Vaccine Clinical Trial Research Team.

Kemenkes_RI. (2021b). Chairman of the ITAGI (Indonesian Technical Advisory Group on Immunization).

Kemenkes_RI. (2021c). Chairman of the PPNI (Indonesian National Nurses Association).

Kemenkes_RI. (2021d). Instagram Posts Related to Holy and Halal.

Kemenkes_RI. (2021e). Instagram Posts Related to Vaccine Quality and Safety.

Kemenkes_RI. (2021f). Ministry of Health Instagram Profile.

Kemkes.go.id. (2021). Angka Positif COVID-19 Tembus 1 Juta, Butuh Komitmen Bersama Kurangi Laju Penularan Virus.

Kompas.com. (2021a). Menkes Tetapkan 7 Jenis Vaksin Covid-19 yang Akan Digunakan Indonesia.

Kompas.com. (2021b). Pesan Kemenkes: Jangan Takut dengan Efek Samping Vaksin Covid19.

Kosterlitz, M., \& Lewis, J. (2017). From baby boomer to millennial: Succession planning for the future. Nurse Leader, 15(6), 396-398.

Krippendorff, K. (2018). Content analysis: An introduction to its methodology. Sage publications. 
Krishen, A. S., Berezan, O., Agarwal, S., \& Kachroo, P. (2016). The generation of virtual needs: Recipes for satisfaction in social media networking. Journal of Business Research, 69(11), 5248-5254.

Leung, L. (2013). Generational differences in content generation in social media: The roles of the gratifications sought and of narcissism. Computers in Human Behavior, 29(3), 997-1006.

Makmun, A., \& Hazhiyah, S. (2020). Tinjauan Terkait Pengembangan Vaksin Covid 19. Molucca Medica, 13(2), 52-59. https://doi.org/10.30598/molmed.2020.v13.i2.52

Murtiningsih, B. S. E. (2016). The Role of Cultural Competence to Overcome Intercultural Communication Conflict: Case study of Indonesian and Korean students in Kyungsung University, South Korea. Mediterranean Journal of Social Sciences. https://doi.org/10.5901/ mjss.2016.v7n6p213

Nabila, F. (2021). Beda 7 Jenis Vaksin COVID-19 yang Akan Dipakai di Indonesia.

Nugroho, R. (2020). Rekap Kasus Corona Indonesia Selama Maret dan Prediksi di Bulan April.

Ong, Y. X., \& Ito, N. (2019). “I want to go there too!" Evaluating social media influencer marketing effectiveness: a case study of Hokkaido's DMO. In Information and communication technologies in tourism 2019 (pp. 132-144). Springer.

Pang, A., Yingzhi Tan, E., Song-Qi Lim, R., Yue-Ming Kwan, T., \& Bhardwaj Lakhanpal, P. (2016). Building effective relations with social media influencers in Singapore. Media Asia, 43(1), 56-68.

Paraskevis, D., Kostaki, E. G., Magiorkinis, G., Panayiotakopoulos, G., Sourvinos, G., \& Tsiodras, S. (2020). Full-genome evolutionary analysis of the novel corona virus (2019-nCoV) rejects the hypothesis of emergence as a result of a recent recombination event. Infection, Genetics and Evolution. https://doi.org/10.1016/j.meegid.2020.104212

Parker, E. B., \& Holsti, O. R. (2006). Content Analysis for the Social Sciences and Humanities. American Sociological Review. https://doi.org/10.2307/2093233

Prasetiawan, E., \& Maulina Ulfa, A. (2017). Civil Society as Peacebuilder in the Internet Era. Global South Review. https://doi.org/10.22146/globalsouth.28848

Rakhmawati, N., Aditama, M., Pratama, R., \& Wiwaha, K. (2020). Analisis Klasifikasi Sentimen Pengguna Media Sosial Twitter Terhadap Pengadaan Vaksin COVID-19. JIEET (Journal of Information Engineering and Educational Technology), 4(2), 90-92.

Rothan, H. A., \& Byrareddy, S. N. (2020). The epidemiology and pathogenesis of coronavirus disease (COVID-19) outbreak. In Journal of Autoimmunity. https://doi.org/10.1016/ j.jaut.2020.102433 
Samiei, D., \& Mehrabi, Z. (2019). Content analysis of the first chapter of the twelfth grade chemistry book based on the william romey's method and determining its importance with the shannon entropy method. 1(3), 53-72.

Situngkir, H. (2004). Epidemiology with Cellular Automata: Case of Study the epidemics of avian flu in Indonesia. BFI Working Paper Series.

Sommerfeldt, E. J., Yang, A., \& Taylor, M. (2019). Public relations channel "repertoires": Exploring patterns of channel use in practice. Public Relations Review. https://doi.org/ 10.1016/j.pubrev.2019.101796

Sun, P., Lu, X., Xu, C., Sun, W., \& Pan, B. (2020). Understanding of COVID-19 based on current evidence. In Journal of Medical Virology. https://doi.org/10.1002/jmv.25722

Susilo, D., Prabowo, T. L., \& Putranto, T. D. (2019). Communicating secure based feeling: Content analysis on indonesian police official account. International Journal of Engineering and Advanced Technology, 8(6), 2541-2543. https://doi.org/10.35940/ ijeat.F8377.088619

Susilo, Daniel, \& Putranto, T. D. (2018). Indonesian Youth on Social Media: Study on Content Analysis. https://doi.org/10.2991/sshr-17.2018.15

World Health Organization. (2020). What is coronavirus?

Zheng, Y. Y., Ma, Y. T., Zhang, J. Y., \& Xie, X. (2020). COVID-19 and the cardiovascular system. In Nature Reviews Cardiology. https://doi.org/10.1038/s41569-020-0360-5 